\title{
Genetic Analysis of Soybean Plant Introductions with Resistance to Phytophthora sojae
}

\author{
S. G. Gordon, S. A. Berry, S. K. St. Martin, and A. E. Dorrance
}

First, second, and fourth authors: Department of Plant Pathology, The Ohio State University, Wooster, OH 44691; and third author: Department of Horticulture and Crop Science, The Ohio State University, Columbus, OH 43210.

Accepted for publication 7 July 2006.

\section{ABSTRACT}

Gordon, S. G., Berry, S. A., St. Martin, S. K., and Dorrance, A. E. 2007. Genetic analysis of soybean plant introductions with resistance to Phytophthora sojae. Phytopathology 97:106-112.

Phytophthora sojae, which causes Phytophthora root and stem rot of soybean, is a serious disease worldwide and is managed primarily by deploying cultivars with resistance. Thirty-two soybean plant introductions (PIs), all but three of which were from South Korea, were proposed as new sources of single-gene resistance to $P$. sojae. The objective of this study was to characterize the inheritance of resistance to $P$. sojae in these PIs. Twenty-two soybean populations from crosses of these PIs and the susceptible cv. Williams were inoculated with $P$. sojae $\mathrm{OH} 17$ (vir $1 \mathrm{~b}, 1 \mathrm{~d}$, 2, 3a, 3b, 3c, 4, 5, 6, 7), and OH25 (vir 1a, 1b, 1c, 1k, 7). These isolates were selected because they are virulent on soybeans with all known Rps

Phytophthora sojae Kaufmann \& Gerdemann (Phytophthora megasperma Drechs. f. sp. glycinea T. Kuan \& D.C. Erwin) causes root and stem rot of soybean (Glycine max L. Merr.), a serious and widespread disease (13). Phytophthora root and stem rot is predominantly managed by deploying single genes that confer resistance to this pathogen. In much of the north central soybean production region that extends from Ohio to Missouri and from North Dakota to Nebraska, Rps1a, Rps1c, and Rps1k are the most common Rps genes in commercial cultivars $(3,4)$. Singlegene resistance has provided effective management of Phytophthora root and stem rot, albeit a single deployed Rps gene may only be effective for 8 to 15 years depending on the environment (22). Pathotypes of $P$. sojae exist with virulence to those soybeans that have many of the resistance genes deployed in commercial soybean cultivars; these pathotypes have been identified in fields throughout the north central region $(1,10,14,15,20,26)$. Rps $1 \mathrm{k}$ was widely deployed during the early 1980 s but only recently has the occurrence of Phytophthora root and stem rot on soybeans with Rps $1 \mathrm{k}$ been identified in commercial fields $(1,2,10,14,15,20,26)$. This indicates that $R p s 1 \mathrm{k}$ conferred resistance to $P$. sojae for at least 20 years. As the complexity of $P$. sojae virulence pathotypes increases, new $R p s$ genes must be identified, existing $R p s$ genes encompassing different loci pyramided together, or Rps genes must be deployed in genetic backgrounds with high levels of partial resistance in order to effectively manage loss of soybean yield.

Plant germ plasm collections are sources of both described and uncharacterized resistance genes for a diversity of pathosystems. New sources of resistance genes have been identified through

Corresponding author: A. E. Dorrance; E-mail address: dorrance.1@ osu.edu

DOI: 10.1094/PHYTO-97-0106

(C) 2007 The American Phytopathological Society genes and many Rps gene combinations. Thirteen of the twenty-two populations had consistent segregation responses following inoculations between the two generations. In two PIs, resistance was conferred by two genes to $\mathrm{OH} 17$ and three genes to $\mathrm{OH} 25$. Resistance to both isolates was conferred by a single gene in PI 398440 although the individual families were not resistant to the same isolates. The data suggest that six of the populations have three-Rps gene combinations as previously proposed, while another four may have either a novel Rps gene or a four-Rps gene combination. Based on this phenotypic analysis, novel and uncharacterized Rps genes may be present in this material. More importantly, these PIs may serve as sources of novel Rps genes that can be used to more effectively manage Phytophthora root and stem rot.

Additional keywords: Glycine max, host resistance. screening with different races (pathotypes) of a specific pathogen. Buchwaldt et al. (6) identified 12 lentil (Lens culinaris [Medik.]) accessions with resistance to Colletotrichum truncatum (Schwein.) out of 1,771 evaluated. In an evaluation of 13 spring barley (Hordeum vulgare L.) accessions, Brooks et al. (5) identified both known and novel genes for resistance to Puccinia hordei G. Otth., the causal agent of leaf rust. The U.S. Department of Agriculture (USDA) Soybean Germplasm Collection is a source of potential new Rps genes and sources of high partial resistance to $P$. sojae $(11,16,17,19,21)$. Lohnes et al. (19) evaluated 726 accessions from central China (plant introduction [PI] numbers 567290 to 567781). All 726 of the PIs were susceptible to one or more of the following $P$. sojae races: 1 , 7, 17, and 25. Kyle et al. (16) evaluated 628 accessions from southern China and found 36 accessions that were resistant to all 10 races of $P$. sojae tested. Kyle et al. (16) also identified three provinces from which a high percentage of resistant accessions originated and concluded that $P$. sojae resistance in China is extremely diverse. In another study, four Japanese PIs were found to harbor multiple known Rps genes including Rps $1 \mathrm{a}, 1 \mathrm{~b}, 1 \mathrm{c}$, and 3 as well as a unique Rps allele, designated Rps? based on responses of segregating populations to 19 different races of P. sojae (21).

Thirty-two accessions, all but three of which are from South Korea, were identified in a previous study as possible new sources of Rps genes (11). In that study, P. sojae isolates with specific virulence pathotypes were chosen for inoculations to assay for all described Rps genes and most two- and three-gene combinations of Rps genes. The 32 PIs identified were resistant to three $P$. sojae isolates with the following virulence pathotypes: $\mathrm{OH} 1$ (vir 7), OH17 (vir 1b, 1d, 2, 3a, 3b, 3c, 4, 5, 6, 7), and OH25 (vir 1a, 1b, $1 \mathrm{c}, 1 \mathrm{k}, 7)$. Collectively, these isolates cause susceptible interactions with all previously identified Rps genes except Rps8. In addition, the 32 PIs were resistant to five $P$. sojae isolates with 
virulence pathotypes chosen to elicit a susceptible response from soybeans with specific two- and three-Rps gene combinations. However, following inoculation with these five isolates, soybeans with the following three-gene combinations-Rps $1 \mathrm{c}, R p s 3 \mathrm{a}$, Rps4; Rps1c, Rps3b, Rps4; Rps1c, Rps2, Rps3a; and Rps1c, Rps2, $R p s 3 \mathrm{~b}$ - still exhibited a resistant response (11). Therefore, these 32 PIs either have one of the above three-Rps gene combinations, a novel Rps gene, or a novel Rps gene in combination with a described Rps gene. One novel gene, $R p s 8$, has already been described from among these 32 PIs (7).

Specific races or pathotypes have been used in other hostpathogen systems to identify the number and expression of resistance genes in a given host. Different pathotypes of Pyrenophora tritici-repentis (Died.) Drechs., were used to characterize resistance genes in wheat (Triticum aestivum L.) (24). Based on a phenotypic analysis, the same recessive gene that controlled resistance to necrosis was identified in all seven cultivars (24). Therefore, it should also be possible to determine how many Rps genes are segregating in soybean populations, and which may have novel genes or combination of genes, based on a phenotypic analysis of $\mathrm{F}_{2: 3}$ and $\mathrm{F}_{2: 4}$ families with well characterized pathotypes (races) of $P$. sojae.

The hypothesis of this study is that selecting a combination of isolates with specific virulence pathotypes to soybeans with all known $R p s$ genes should expedite the process of identifying novel genes in PIs with multiple Rps genes. Rps 8 is considered a novel gene in this study, primarily due to its recent discovery (7). Much of this research was completed prior to and during the time the gene was characterized.

Table 1 briefly outlines expected outcomes of $F_{2: 3}$ and $F_{2: 4}$ populations following inoculation with three specific pathotypes of $P$. sojae. For example, if a population is segregating for a novel single gene, then following inoculation with race 1 (vir Rps7), an $\mathrm{F}_{2: 3}$ population should segregate 3 resistant: 1 susceptible. If there's one novel gene in this PI parent that confers resistance to all $P$. sojae races used, then all of the $\mathrm{F}_{2: 3}$ families would have the same response to all $P$. sojae isolates. If the $\mathrm{F}_{2: 3}$ families did not have the same response, then there exists the possibility of uncharacterized virulence pathotypes within the isolates to the Rps genes in this PI.

The scenario is different for PIs where multiple Rps genes are present. If two Rps genes are present in the PI, assuming one of the genes is not Rps7, then after inoculation with race 1 a $15: 1$ segregation ratio in $\mathrm{F}_{2}$ plants is expected. P. sojae isolate $\mathrm{OH} 17$ has virulence to soybeans with $R p s 1 \mathrm{~b}, 1 \mathrm{~d}, 2$, 3a, 3b, 3c, 4, 5, 6, and 7, and $\mathrm{OH} 25$ has virulence to soybeans with Rps $1 \mathrm{a}, 1 \mathrm{~b}, 1 \mathrm{c}$, $1 \mathrm{k}$, and 7 . In a population with a combination of two novel genes, a 15:1 segregation ratio is expected to both isolates. If there is a novel gene present in combination with one known Rps gene, then one expects a 15:1 ratio to the isolate that lacked virulence to the soybeans with the known Rps gene and a 3:1 ratio for reaction to the isolate which has virulence to soybeans with the known Rps gene.

Based on a previous study (11) there is also the possibility of four three-gene combinations in these PIs: Rps1c, Rps3a, Rps 4 ; Rps1c, Rps3b, Rps4; Rps1c, Rps2, Rps3a; and Rps1c, Rps2, $R p s 3 b$. $P$. sojae isolate $\mathrm{OH} 25$ has virulence to soybeans with $R p s 1 \mathrm{c}$ and $\mathrm{OH} 17$ has virulence to soybeans with $R p s 2, R p s 3 \mathrm{a}$, Rps 3b, and Rps4. In these cases, following inoculation with OH17, a 3:1 ratio is expected where Rps 1c is segregating. Conversely, in the same population, following inoculations with $\mathrm{OH} 25$, a 15:1 ratio is expected for soybeans with the combinations of Rps3a and Rps4; Rps $3 \mathrm{~b}$ and 4; Rps 2 and 3a; and Rps 2 and $3 b$.

The objectives of this study were to determine the number of $R p s$ genes in these PIs by following segregation ratios in soybean populations derived from crosses between these resistant PIs and the susceptible cv. Williams, and based on this phenotypic analysis, determine which of these PIs may have a novel gene.

\section{MATERIALS AND METHODS}

Plant material. Soybean PIs and the cv. Williams were obtained from the USDA Soybean Germplasm Collection in Urbana, IL. The PIs used in this study were first characterized by Dorrance and Schmitthenner (11) as resistant to eight $P$. sojae races, including 1, 17, and 25. Most of the PIs listed in Table 2 originated from South Korea. The crosses used to evaluate the PIs were Williams $(r p s / r p s) \times$ PI $($ Rps unknown). Williams was the seed parent for all crosses, except those with PIs 398440 and 424247A, in which it was the pollen parent. Plants derived from accidental self-fertilization were distinguished from $F_{1}$ hybrids based on flower color and plant type in the $\mathrm{F}_{1}$. The $\mathrm{F}_{1}$ plants from each of these crosses were allowed to self-pollinate to produce

TABLE 1. Expected ratios for $\mathrm{F}_{2: 3}$ families segregating for resistance following inoculation with isolates of Phytophthora sojae with specific virulence pathotypes

\begin{tabular}{|c|c|c|c|c|}
\hline $\begin{array}{l}\text { Number and type of Rps gene in plant } \\
\text { introduction (PI) }\end{array}$ & $\begin{array}{c}\mathrm{OH} 25 \\
(1 \mathrm{a}, 1 \mathrm{~b}, 1 \mathrm{c}, 1 \mathrm{k}, 7)\end{array}$ & $\begin{array}{c}\text { OH17 } \\
(1 \mathrm{~b}, 1 \mathrm{~d}, 2,3 \mathrm{a}, 3 \mathrm{~b}, 3 \mathrm{c}, 4,5,6,7)\end{array}$ & Comments & Additional inoculations \\
\hline \multicolumn{5}{|l|}{ No unidentified virulence } \\
\hline One novel gene & $3: 1$ & $3: 1$ & All families should be the same. & None \\
\hline $\begin{array}{l}\text { One novel plus known gene ( } \mathrm{S} \text { to } \\
\text { OH25) }\end{array}$ & $3: 1$ & $15: 1$ & $\begin{array}{l}\text { Families } \mathrm{S} \text { to } \mathrm{OH} 1 \text { and } \mathrm{OH} 17 \\
\text { should be the same. }\end{array}$ & $\begin{array}{l}\text { Additional inoculations with } \\
\text { isolates with virulence to } 1 \mathrm{a}, 1 \mathrm{~b} \text {, } \\
\text { or } 1 \mathrm{c} \text { can be used to identify } \\
\text { which known Rps allele is } \\
\text { present. }\end{array}$ \\
\hline $\begin{array}{l}1 \mathrm{c}, 3 \mathrm{a}, 4 \\
1 \mathrm{c}, 3 \mathrm{~b}, 4 \\
1 \mathrm{c}, 2,3 \mathrm{a}\end{array}$ & $15: 1$ & $3: 1$ & $\begin{array}{l}\text { Family that is } \mathrm{S} \text { to } \mathrm{OH} 1 \text { should be } \\
\mathrm{S} \text { to all races. } \\
\text { Families } \mathrm{S} \text { to } \mathrm{OH} 25 \text { and }\end{array}$ & $\begin{array}{l}\text { Inoculate with an isolate with } 1 \mathrm{c} \text {, } \\
3 \mathrm{a} \text {, or } 1 \mathrm{c}, 3 \mathrm{~b} \text { virulence to } \\
\text { confirm. If true, should be } 3: 1 \text {. }\end{array}$ \\
\hline $1 \mathrm{c}, 2,3 \mathrm{~b}$ & & & OH17 may be different. & \\
\hline \multicolumn{5}{|l|}{ Undescribed virulence } \\
\hline Two genes & $3: 1$ & $3: 1$ & Susceptible families are & Additional isolates may \\
\hline 1 is & $15: 1$ & $3: 1$ & different among the isolates. & give similar or different patterns. \\
\hline undescribed & $3: 1$ & $15: 1$ & & \\
\hline
\end{tabular}


populations of approximately 100 to $300 \mathrm{~F}_{2}$. The $\mathrm{F}_{2}$ plants were selfed and each plant was threshed individually to yield $\mathrm{F}_{2: 3}$ seed. These $\mathrm{F}_{2: 3}$ families were used for inoculations with the $P$. sojae isolates. Approximately 20 to 70 remnant $F_{2: 3}$ seeds per family from all populations (Table 3 ) were planted and increased. $\mathrm{F}_{4}$ seeds were bulk-harvested from each family, from 40 to $50 \mathrm{~F}_{3}$ plants, and $\mathrm{F}_{2: 4}$ seedlings were used for inoculations as described below.

$\boldsymbol{P}$. sojae inoculations. To determine how many genes were present in these PIs, three isolates of $P$. sojae were used in this study; all were maintained at the Department of Plant Pathology, Ohio Agricultural Research and Development Center (OARDC), Wooster, $\mathrm{OH}$, and were collected in Ohio from soybeans with Phytophthora stem rot. These isolates were shared with all of the land grant universities in the north central region in September 2002 as well as being deposited in the National Soybean Pathogen Collection Center at the University of Illinois, Urbana, IL. Initially, $P$. sojae race 1 isolate $\mathrm{OH} 1$ (vir 7) was used to inoculate 100 7-day-old $\mathrm{F}_{2}$ seedlings to determine the number of Rps genes in the PI. P. sojae isolates $\mathrm{OH} 25$ (vir 1a, 1b, 1c, 1k, 7) and $\mathrm{OH} 17$ (vir 1b, 1d, 2, 3a, 3b, 3c, 4, 5, 6, 7) were used to inoculate 10 to 20 seedlings from each $\mathrm{F}_{2: 3}$ family. For each population, between 35 and 277 families were evaluated, depending on the number of seeds available per family and the size of the population (Table 2). Fifteen to twenty-five $F_{2: 4}$ seedlings were inoculated (Table 3 ).

The seedlings were inoculated using a variation of the hypocotyl inoculation technique $(7,23)$. Briefly, seeds were placed between germination paper wetted with water, rolled up, and stored in the dark in plastic containers on top of wire mesh. Seven days later, the germination papers were unrolled and the seedlings were inoculated. A 7-day-old culture of $P$. sojae grown on lima bean (Phaseolus lunatus L.) agar (50 g of lima beans, $12 \mathrm{~g}$ of agar per liter) was cut and placed in a hypodermic syringe and then the agar was forced through the syringe to create a slurry. The slurry was placed back into the syringe and seedlings were inoculated by scratching the hypocotyl with the needle of the hypodermic syringe and placing 0.2 to $0.4 \mathrm{ml}$ of the agar/mycelium mixture onto the wound. Following inoculation, the towels were re-rolled and placed back into plastic containers as before. Seven days after inoculation the seedlings were scored for disease reactions. Individual $\mathrm{F}_{2}$ seedlings were scored as either resistant (R) or susceptible (S). Individuals with a brown expanding lesion were scored as $\mathrm{S}$ and those with a necrotic lesion restricted to the inoculation site were scored as $\mathrm{R}$. The $\mathrm{F}_{2: 3}$ and $\mathrm{F}_{2: 4}$ families were scored based on the percentage of seedlings with susceptible reactions. Families in which 0 to $20 \%, 21$ to $79 \%$, or 80 to $100 \%$ of the seedlings developed lesions were designated as $\mathrm{R}$, heterozygous $(\mathrm{H})$, or $\mathrm{S}$, respectively. The segregation ratios represented the $\mathrm{F}_{2}$ plant genotype, and for purposes of calculating chi-square statistics and maximum likelihoods, the $\mathrm{R}$ and $\mathrm{H}$ classes were combined.

Differential checks were used in each test to ensure that the isolates were consistent in their reaction to corresponding pathotypes. The differentials used in this study were 'Williams' (universal susceptible); 'Harlon' (Rps1a), 'Harosoy 13XX' (Rps1b), 'Williams 79' (Rps1c); PI103091 (Rps1d); 'Williams 82' (Rps 1k); L76-1988 (Rps2); L83-570 (Rps3); PRX 146-36 (Rps3b); PRX 145-48 (Rps3c); L85-2352 (Rps4); L85-3059 (Rps5); and 'Harosoy 62XX' (Rps6) and 'Harosoy' (Rps7).

Statistical analysis. To estimate the number of resistance genes in each of these PIs, segregation data for response to both isolates were used to calculate the likelihood (27) for models with one, two, three, or four resistance genes for each population. The model equation for a single-gene model $(0.75 \mathrm{R}$ and $0.25 \mathrm{~S})$ was $(\mathrm{R}+\mathrm{H}) \times \log (0.75)+\mathrm{S} \times \log (0.25)$, where $\mathrm{R}=$ the frequency of the resistant class, $\mathrm{H}=$ that of the heterozygous class, and $\mathrm{S}=$ that of the susceptible class. The two-, three-, and four-gene values were computed using the appropriate segregation proportions of $15 / 16$ and 1/16, 63/64 and 1/64, and 255/256 and 1/256, respectively. Where the model incorporated more than one locus, the assumption was of independently segregating loci with duplicate (or triplicate or quadruplicate) gene action (epistasis). These expected proportions were used to obtain the common logarithm of the likelihood function for each model. The model with the maximum likelihood was selected and considered significantly $(P<0.01)$ better than the other models if its $\log$ likelihood had a smaller negative value than the others by two or

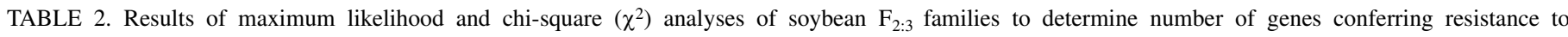
Phytophthora sojae OH17 (1b, 1d, 2, 3a, 3b, 3c, 4, 5, 6, 7) in plant introductions (PI) crossed to the susceptible cv. Williams

\begin{tabular}{|c|c|c|c|c|c|c|c|c|c|}
\hline \multirow[b]{2}{*}{ PI } & \multicolumn{9}{|c|}{$\mathrm{F}_{2: 3}$ family reactions ${ }^{\mathrm{a}}$ for $P$. sojae $\mathrm{OH} 17$} \\
\hline & $\mathrm{R}$ & $\mathrm{H}$ & $\mathrm{S}$ & $\log \mathrm{L} 1^{\mathrm{b}}$ & $\log \mathrm{L} 2$ & $\log \mathrm{L} 3$ & Ratio & $\chi^{2}$ & $P$ \\
\hline 273483D & 35 & 37 & 26 & -47.9 & -55.0 & -69.8 & $3: 1$ & 0.12 & 0.73 \\
\hline 274456 & 52 & 67 & 35 & -72.5 & -81.0 & -101.8 & $3: 1$ & 0.42 & 0.51 \\
\hline 398295 & 47 & 64 & 41 & -72.2 & -85.5 & -110.3 & $3: 1$ & 0.32 & 0.57 \\
\hline 398440 & 28 & 43 & 23 & -43.6 & -50.7 & -65.0 & $3: 1$ & 0.01 & 0.91 \\
\hline 398643 & 33 & 44 & 23 & -47.0 & -52.8 & -66.6 & $3: 1$ & 0.21 & 0.64 \\
\hline 398666 & 21 & 44 & 29 & -43.3 & -55.7 & -74.6 & $3: 1$ & 1.72 & 0.19 \\
\hline 398693 & 42 & 68 & 25 & -60.8 & -65.7 & -81.8 & $3: 1$ & 3.03 & 0.08 \\
\hline 398694 & 27 & 46 & 28 & -47.0 & -57.3 & -75.0 & $3: 1$ & 0.40 & 0.53 \\
\hline 398697 & 33 & 61 & 40 & -62.3 & -78.4 & -104.0 & $3: 1$ & 1.68 & 0.19 \\
\hline 399036 & 28 & 55 & 27 & -49.7 & -59.1 & -76.9 & $3: 1$ & 0.01 & 0.91 \\
\hline 399079 & 83 & 95 & 19 & -90.0 & -81.3 & -91.2 & $15: 1$ & 3.87 & 0.05 \\
\hline 404159 & 41 & 29 & 18 & -44.3 & -45.1 & -53.6 & $3: 1$ & 0.97 & 0.32 \\
\hline $407861 \mathrm{C}$ & 58 & 57 & 24 & -66.5 & -66.9 & -79.4 & $3: 1$ & 4.4 & 0.04 \\
\hline 407974B & 25 & 53 & 22 & -44.3 & -51.4 & -66.4 & $3: 1$ & 0.48 & 0.49 \\
\hline 408029 & 22 & 52 & 19 & -40.3 & -46.4 & -59.9 & $3: 1$ & 1.04 & 0.31 \\
\hline 408097 & 22 & 38 & 31 & -43.3 & -56.7 & -76.1 & $3: 1$ & 3.99 & 0.05 \\
\hline 408211B & 36 & 32 & 17 & -41.5 & -43.0 & -51.8 & $3: 1$ & 1.13 & 0.29 \\
\hline $408319 \mathrm{C}$ & 16 & 38 & 22 & -34.3 & -43.7 & -58.4 & $3: 1$ & 0.63 & 0.43 \\
\hline 416840 & 22 & 35 & 21 & -36.4 & -43.7 & -56.9 & $3: 1$ & 0.15 & 0.69 \\
\hline 417229 & 32 & 49 & 25 & -49.1 & -56.3 & -71.9 & $3: 1$ & 0.11 & 0.74 \\
\hline 424247A & 74 & 132 & 71 & -127.0 & -151.8 & -197.5 & $3: 1$ & 0.06 & 0.81 \\
\hline 424354 & 51 & 66 & 12 & -57.8 & -52.6 & -59.6 & $15: 1$ & 2.05 & 0.15 \\
\hline
\end{tabular}

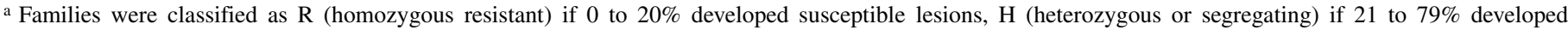
susceptible lesions, and S (homozygous susceptible) if 80 to $100 \%$ developed susceptible lesions.

${ }^{\mathrm{b}} \mathrm{Log} \mathrm{Ln}$ refers to the logarithm of the likelihood associated with a model positing $\mathrm{n}$ segregating Rps genes. L1 = one gene, L2 = two genes, and L3 = three genes. 
more units, corresponding to a likelihood ratio of 100 or more (Tables 2 through 5).

Chi-square analyses were also performed using SAS (version 9.1, SAS Institute, Cary, NC) to test for goodness of fit to the gene model of one, two, or three genes that was most likely. For chi-square analysis, the $\mathrm{F}_{2: 3}$ and $\mathrm{F}_{2: 4}$ data were pooled to reconstitute an $\mathrm{F}_{2}$ genotype for analysis.

\section{RESULTS}

$\mathbf{F}_{2}$ populations. One hundred $\mathrm{F}_{2}$ plants from 17 of the $22 \mathrm{PI} \times$ Williams crosses were inoculated with $\mathrm{OH} 1$ for a preliminary analysis. Populations PI 273483D, 274456, 398440, 398643, 398666, 398693, 398694, 398697, 399036, 407974B, 408029, 408097, 408211B, 408319C, 416840, 417229, and 424247A did not have segregation ratios consistent with a single Rps gene as confirmed by chi-square analyses (data not shown). The number of susceptible plants ranged from 0 to 14 for all populations. While the number of plants inoculated was too small to completely distinguish between two and three Rps genes, these results indicate that each of these PIs have more than one independent Rps locus. For all inoculations the differential checks responded as expected (data not shown).

$\mathbf{F}_{2: 3}$ populations. Data for the resistance response were collected from 22 PI populations following inoculation with P. sojae $\mathrm{OH} 17$ and $\mathrm{OH} 25$ (Tables 2 and 3 ). In all populations, resistance to $P$. sojae was inherited as a dominant trait (Tables 2 and 3). For PI398440, resistance to both $\mathrm{OH} 17$ and $\mathrm{OH} 25$ was conferred by a single gene, based on maximum likelihood and chi-square analyses (Tables 2 and 3). However, some individual $\mathrm{F}_{2: 3}$ and $\mathrm{F}_{2: 4}$ families were homozygous resistant to $\mathrm{OH} 17$ and homozygous susceptible to $\mathrm{OH} 25$, while others were homozygous resistant to $\mathrm{OH} 25$ and homozygous susceptible to OH17. This indicates that PI398440 has two Rps genes: one that confers resistance to $P$. sojae $\mathrm{OH} 17$, and a second that confers resistance to $P$. sojae $\mathrm{OH} 25$.

Resistance to $P$. sojae $\mathrm{OH} 17$ was conferred by a single gene in 18 populations (Table 2) and resistance to $P$. sojae $\mathrm{OH} 25$ was conferred by two or three genes in 8 and 11 populations (Table 3 ), respectively. For two of the populations resistant to $\mathrm{OH} 17$, the chi-square value $P$ value was less than or equal to 0.05 (Table 2). Similarly, the chi-square $P$ value for two genes conferring resistance to $\mathrm{OH} 25$ was less than 0.05 in two populations. Results for eight populations with resistance conferred by one gene to P. sojae $\mathrm{OH} 17$ and two genes to $\mathrm{OH} 25$ indicate that these populations may have one of the four three-gene combinations proposed in a previous study (11). Many of the $\mathrm{F}_{2: 3}$ populations resistant to $P$. sojae $\mathrm{OH} 25$ had no or very few $(<3)$ homozygous susceptible families.

Resistance to $P$. sojae OH17 expressed in PIs 399079 and 424354 was conferred by two genes, and resistance to $\mathrm{OH} 25$ by two or three genes, based on chi-square and maximum likelihood analyses. $P$. sojae $\mathrm{OH} 17$ has virulence to soybeans with genes that exist at all Rps loci except Rps8; thus, resistance conferred by two genes is a strong indication of a novel gene.

$\mathbf{F}_{\text {2:4 }}$ populations. Twenty-two $\mathrm{F}_{2: 4}$ populations were inoculated with $\mathrm{OH} 17$ and $\mathrm{OH} 25$, respectively (Tables 4 and 5). Results from the maximum likelihood and chi-square analyses indicate that all but two of the populations (PI408029 and 417229) had consistent segregation ratios for $P$. sojae $\mathrm{OH} 17$ between the $\mathrm{F}_{2: 3}$ and $\mathrm{F}_{2: 4}$ generations (Tables 2 and 4). For these two PIs, there was not a good fit to a single gene segregation ratio in the $\mathrm{F}_{2: 4}$ generation (Table 4). In addition, four additional populations, 398295, 398697, 408097, and 424354 had the same 3:1 segregation ratios, but the chi-square $P$ values were $\leq 0.05$ and were primarily skewed toward the resistant and heterozygous classes. For $P$. sojae $\mathrm{OH} 25$ (Tables 3 and 5), 16 populations segregated in the same ratio as their respective $\mathrm{F}_{2: 3}$ counterparts, confirming those results. PI populations 274456, 398666, 398693, 398697, 408029, and 408319C had different segregation ratios between the $F_{2: 3}$ and $F_{2: 4}$ populations. For PI398666, 90\% or more of the plants developed lesions in seven of the families in the susceptible class of the $\mathrm{F}_{2: 3}$, while in the corresponding $\mathrm{F}_{2: 4}$ families only 30 to $50 \%$ of the plants developed lesions following inoculation, thus classifying them as heterozygous. For PI398693, the discrepancy between generations may be that fewer families were evaluated in the $F_{2: 3}$ compared with the $\mathrm{F}_{2: 4}$ generation (35 and 56 families, respectively) (Tables 3 and 5). For example, in 398693, 0 of the

TABLE 3. Results of maximum likelihood and chi-square $\left(\chi^{2}\right)$ analyses of soybean $F_{2: 3}$ families to determine number of genes conferring resistance to Phytophthora sojae $\mathrm{OH} 25$ (vir Rps1a, 1b, 1c, 1k, 7) in plant introductions (PI) crossed to the susceptible cv. Williams

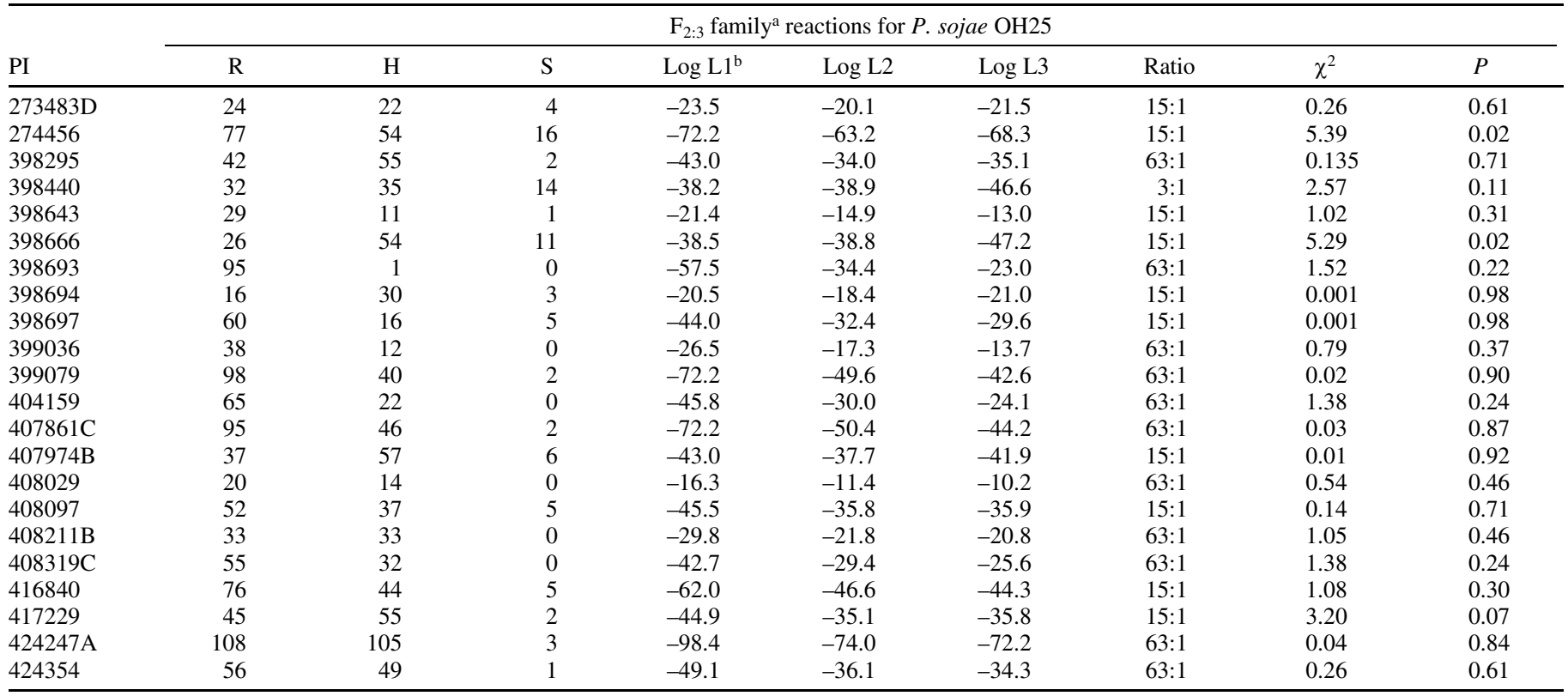

${ }^{a}$ Families were classified as $\mathrm{R}$ (homozygous resistant) if 0 to $20 \%$ developed susceptible lesions, $\mathrm{H}$ (heterozygous or segregating) if 21 to $79 \%$ developed susceptible lesions, and S (homozygous susceptible) if 80 to $100 \%$ developed susceptible lesions.

${ }^{\mathrm{b}} \mathrm{Log} \mathrm{Ln}$ refers to the logarithm of the likelihood associated with a model positing $\mathrm{n}$ segregating Rps genes. $\mathrm{L} 1=$ one gene, $\mathrm{L} 2=\mathrm{two}$ genes, and L3 $=$ three genes. 


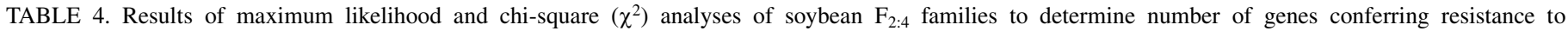
Phytophthora sojae OH17 (vir Rps1b, 1d, 2, 3a, 3b, 3c, 4, 5, 6, 7) in plant introductions (PI) crossed to the susceptible cv. Williams

\begin{tabular}{|c|c|c|c|c|c|c|c|c|c|}
\hline \multirow[b]{2}{*}{ PI } & \multicolumn{9}{|c|}{$\mathrm{F}_{2: 4}$ family ${ }^{\mathrm{a}}$ reactions for $P$. sojae $\mathrm{OH} 17$} \\
\hline & $\mathrm{R}$ & $\mathrm{H}$ & $\mathrm{S}$ & $\log \mathrm{L} 1^{\mathrm{b}}$ & $\log \mathrm{L} 2$ & $\log \mathrm{L} 3$ & Ratio & $\chi^{2}$ & $P$ value \\
\hline 273483D & 31 & 54 & 25 & -50.0 & -57.5 & -73.7 & $3: 1$ & 0.30 & 0.58 \\
\hline 274456 & 25 & 62 & 22 & -47.0 & -54.1 & -69.9 & $3: 1$ & 1.35 & 0.25 \\
\hline 398295 & 33 & 94 & 23 & -62.0 & -67.8 & -86.2 & $3: 1$ & 7.48 & 0.006 \\
\hline 398440 & 24 & 48 & 22 & -42.1 & -49.6 & -64.2 & $3: 1$ & 0.13 & 0.72 \\
\hline 398643 & 30 & 61 & 36 & -58.1 & -72.5 & -96.0 & $3: 1$ & 0.76 & 0.38 \\
\hline 398666 & 14 & 41 & 24 & -35.2 & -46.3 & -62.7 & $3: 1$ & 1.22 & 0.27 \\
\hline 398693 & 25 & 26 & 23 & -36.7 & -44.5 & -57.7 & $3: 1$ & 1.46 & 0.23 \\
\hline 398694 & 35 & 53 & 24 & -51.5 & -57.4 & -72.4 & $3: 1$ & 0.76 & 0.38 \\
\hline 398697 & 42 & 34 & 14 & -17.9 & -19.0 & -25.8 & $3: 1$ & 4.28 & 0.04 \\
\hline 399036 & 28 & 52 & 31 & -51.2 & -63.0 & -83.0 & $3: 1$ & 0.51 & 0.48 \\
\hline 399079 & 39 & 40 & 6 & -13.5 & -9.4 & -11.4 & $15: 1$ & 0.09 & 0.76 \\
\hline 404159 & 41 & 33 & 20 & -46.7 & -48.7 & -58.8 & $3: 1$ & 0.70 & 0.40 \\
\hline $407861 \mathrm{C}$ & 33 & 36 & 15 & -39.7 & -40.7 & -49.0 & $3: 1$ & 2.29 & 0.13 \\
\hline 407974B & 23 & 50 & 17 & -19.4 & -22.5 & -31.2 & $3: 1$ & 1.79 & 0.18 \\
\hline 408029 & 36 & 44 & 10 & -16.1 & -15.4 & -20.4 & $15: 1$ & 5.29 & 0.02 \\
\hline 408097 & 36 & 31 & 12 & -15.6 & -16.3 & -22.1 & $3: 1$ & 4.05 & 0.05 \\
\hline 408211B & 17 & 50 & 23 & -39.1 & -48.8 & -65.1 & $3: 1$ & 0.02 & 0.90 \\
\hline 408319C & 20 & 56 & 24 & -43.3 & -52.9 & -70.0 & $3: 1$ & 0.05 & 0.82 \\
\hline 416840 & 6 & 25 & 10 & -17.2 & -21.7 & -29.3 & $3: 1$ & 0.01 & 0.93 \\
\hline 417229 & 55 & 44 & 14 & -20.8 & -19.6 & -26.0 & $15: 1$ & 7.27 & 0.01 \\
\hline 424247A & 26 & 46 & 18 & -19.8 & -23.7 & -33.0 & $3: 1$ & 1.20 & 0.27 \\
\hline 424354 & 68 & 48 & 14 & -63.8 & -55.7 & -60.2 & $15: 1$ & 4.53 & 0.03 \\
\hline
\end{tabular}

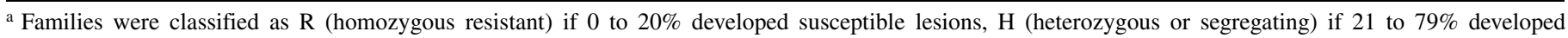
susceptible lesions, and S (homozygous susceptible) if 80 to $100 \%$ developed susceptible lesions.

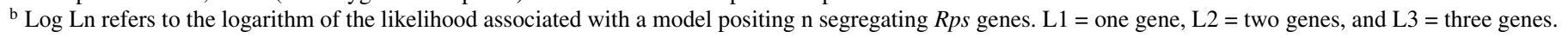

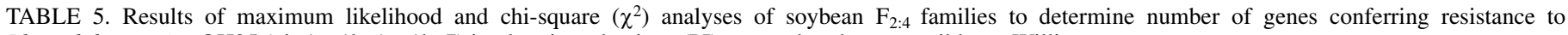
Phytophthora sojae $\mathrm{OH} 25$ (vir 1a, 1b, 1c, 1k, 7) in plant introductions (PI) crossed to the susceptible cv. Williams

\begin{tabular}{|c|c|c|c|c|c|c|c|c|c|}
\hline \multirow[b]{2}{*}{ PI } & \multicolumn{9}{|c|}{$\mathrm{F}_{2: 4}$ familya reactions for $P$. sojae $\mathrm{OH} 25$} \\
\hline & $\mathrm{R}$ & $\mathrm{H}$ & $\mathrm{S}$ & $\log \mathrm{L} 1^{\mathrm{b}}$ & $\log \mathrm{L} 2$ & Log L3 & Ratio & $\chi^{2}$ & $P$ value \\
\hline 273483D & 27 & 80 & 3 & -15.2 & -6.6 & -6.2 & $15: 1$ & 2.33 & 0.13 \\
\hline 274456 & 79 & 29 & 1 & -14.1 & -4.2 & -2.5 & $63: 1$ & 0.29 & 0.59 \\
\hline 398295 & 27 & 18 & 0 & -5.6 & -1.3 & -0.3 & $63: 1$ & 0.71 & 0.41 \\
\hline 398440 & 24 & 49 & 15 & -18.2 & -20.1 & -27.6 & $3: 1$ & 2.97 & 0.08 \\
\hline 398643 & 45 & 45 & 6 & -14.9 & -9.7 & -11.5 & $15: 1$ & 0.0 & 1.0 \\
\hline 398666 & 35 & 42 & 0 & -9.6 & -2.2 & -0.5 & $63: 1$ & 1.22 & 0.27 \\
\hline 398693 & 36 & 44 & 17 & -20.2 & -22.7 & -31.3 & $3: 1$ & 2.89 & 0.09 \\
\hline 398694 & 46 & 62 & 6 & -17.1 & -10.3 & -11.6 & $15: 1$ & 0.19 & 0.66 \\
\hline 398697 & 61 & 32 & 0 & -11.6 & -2.6 & -0.6 & $63: 1$ & 1.48 & 0.22 \\
\hline 399036 & 64 & 35 & 3 & -50.9 & -37.1 & -34.3 & $63: 1$ & 1.23 & 0.26 \\
\hline 399079 & 54 & 28 & 1 & -10.8 & -3.5 & -2.4 & $63: 1$ & 0.07 & 0.79 \\
\hline 404159 & 64 & 25 & 0 & -46.1 & -30.5 & -25.0 & $63: 1$ & 1.41 & 0.23 \\
\hline $407861 \mathrm{C}$ & 57 & 30 & 2 & -44.6 & -31.9 & -28.9 & $63: 1$ & 0.27 & 0.60 \\
\hline 407974B & 48 & 32 & 1 & -10.6 & -3.4 & -2.4 & $15: 1$ & 3.48 & 0.06 \\
\hline 408029 & 48 & 40 & 5 & -14.0 & -8.5 & -9.6 & $15: 1$ & 0.12 & 0.73 \\
\hline 408097 & 59 & 24 & 3 & -12.2 & -5.9 & -6.0 & $15: 1$ & 1.36 & 0.24 \\
\hline 408211B & 39 & 46 & 1 & -11.2 & -3.6 & -2.4 & $63: 1$ & 0.09 & 0.77 \\
\hline 408319C & 42 & 47 & 8 & -15.9 & -12.1 & -15.1 & $15: 1$ & 0.66 & 0.41 \\
\hline 416840 & 18 & 17 & 2 & -5.6 & -3.4 & -3.9 & $15: 1$ & 0.04 & 0.83 \\
\hline 417229 & 66 & 44 & 4 & -16.2 & -7.9 & -8.0 & $15: 1$ & 1.46 & 0.23 \\
\hline 424247A & 53 & 33 & 3 & -12.6 & -6.0 & -6.0 & $63: 1$ & 1.89 & 0.17 \\
\hline 424354 & 75 & 33 & 2 & -14.7 & -5.4 & -4.4 & $63: 1$ & 0.05 & 0.83 \\
\hline
\end{tabular}

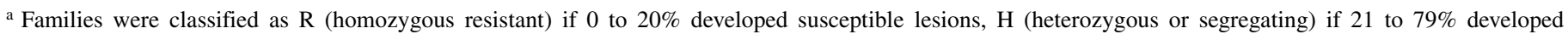
susceptible lesions, and S (homozygous susceptible) if 80 to $100 \%$ developed susceptible lesions.

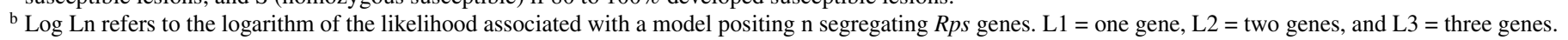

35 families were homozygous susceptible in the $F_{2: 3}$ compared with two homozygous susceptible families out of the 56 evaluated in the $\mathrm{F}_{2: 4}$.

Based on the best fit to both the maximum likelihood and chisquare analyses, the putative number of Rps genes is summarized in Table 6. Novel genes or Rps 8 may exist in 7 of the 22 PIs evaluated in this study. However, many of these are in combinations with known genes, and the potential for pre-existing virulence may also exist. In addition, PIs with the three known gene combinations of Rps $1 \mathrm{c}$ and Rps $2,3 \mathrm{a}, 3 \mathrm{~b}$, or 4 were also identified.

\section{DISCUSSION}

In soybeans, 14 Rps genes have been described across eight loci (13). In this study, two $P$. sojae isolates with complex pathotypes and virulence to soybeans with all of the described Rps genes were selected in order to identify novel genes. One of the hypotheses developed from an earlier study (11) was that these PIs harbor three Rps-gene combinations. Rps 1c confers resistance to $P$. sojae $\mathrm{OH} 17$, while $R p s$ genes $2,3 \mathrm{a}, 3 \mathrm{~b}$, and 4 confer resistance to $\mathrm{OH} 25$. For six of the PIs in this study, a 3:1 ratio to $\mathrm{OH} 17$ and a 15:1 ratio for $\mathrm{OH} 25$ was found. 


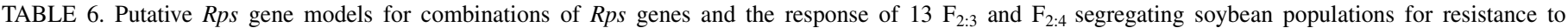
Phytophthora sojae isolates OH17 (vir 1b, 1d, 2, 3a, 3b, 3c, 4, 5, 6, 7) and OH25 (vir 1a, 1b, 1c, 1k, 7)

\begin{tabular}{|c|c|c|c|}
\hline \multirow[b]{2}{*}{ Rps gene model ${ }^{\mathrm{a}}$} & \multicolumn{2}{|c|}{$\begin{array}{l}\text { Segregation ratio }\left(\mathrm{R}: \mathrm{S}^{\mathrm{b}}\right) \\
\quad \text { P. sojae isolate }\end{array}$} & \multirow{2}{*}{$\begin{array}{l}\text { Plant introduction (PI) populations that fit the } \\
\text { proposed gene model }\end{array}$} \\
\hline & $\mathrm{OH} 17$ & $\mathrm{OH} 25$ & \\
\hline One novel gene & $3: 1$ & $3: 1$ & None (PI 399073, [7]) \\
\hline Two novel & $15: 1$ & $63: 1$ & 399079,424354 \\
\hline One novel plus known gene $\mathrm{S}$ to $\mathrm{OH} 25$ & $15: 1$ & $3: 1$ & None \\
\hline 1b plus novel gene & $3: 1$ & $3: 1$ & None \\
\hline Rps 1c, 3a, 4 & $3: 1$ & $15: 1$ & 273483D, 398643, 398694, 407974B, \\
\hline Rps $1 \mathrm{c}, 3 \mathrm{~b}, 4$ & & & 408097,416840 \\
\hline \multicolumn{4}{|l|}{ Rps $1 \mathrm{c}, 2,3 \mathrm{a}$} \\
\hline \multicolumn{4}{|l|}{ Rps $1 \mathrm{c}, 2,3 \mathrm{~b}$} \\
\hline Rps $1 \mathrm{c}, 2,3$ (a or b), 4, or novel plus known & $3: 1$ & $63: 1$ & $399036,404159,408211 B, 424247 \mathrm{~A}$ \\
\hline Two novel ${ }^{\mathrm{c}}$ & $3: 1$ & $3: 1$ & 398440 \\
\hline
\end{tabular}

a $R p s 8$ is considered a novel gene in this study primarily due to its recent discovery.

${ }^{\mathrm{b}} \mathrm{R}: \mathrm{S}$ indicates ratio of the number of families with resistant/susceptible response following inoculation.

${ }^{c}$ May be due to undescribed virulence, since the families did not respond similarly to both isolates.

This is consistent with the hypothesis that these PIs contain three independent Rps loci. In order to determine exactly which Rps loci these PIs contain, crosses to differentials containing characterized single $R p s$ genes are required. In order to accurately classify each PI in this manner, each of these populations that fit the three-gene hypothesis must be crossed to at least three different isolines. This would result in a total of 18 very large populations with three to four segregating Rps genes that could be used to characterize the response to the appropriate $P$. sojae isolates. In addition, results for the four populations in which three genes confer resistance to $\mathrm{OH} 25$ and one gene confers resistance to $\mathrm{OH} 17$ could indicate the presence of novel loci or of a four-Rps gene combination of Rps $1 \mathrm{c}, 2,3$ (a or c), and 4. These four PIs originate from three different regions in South Korea and one in Georgia, Russia.

In addition, based on a genetic diversity analysis of this germ plasm, the PIs from each province clustered separately (8). Thus, it would seem unlikely that this diverse group of soybean germ plasm would all contain the same four-Rps gene combination. Another possibility is that the PIs contain novel, uncharacterized Rps alleles at these loci (11). Two PIs in this study have potentially novel Rps loci or genes, including Rps8, based on segregation ratios of their $\mathrm{F}_{2}$-derived progeny. These include 399079 and 424354 based on their 15:1 segregation for resistance to $P$. sojae $\mathrm{OH} 17$ and 63:1 to $\mathrm{OH} 25$. $P$. sojae $\mathrm{OH} 17$ is virulent to soybeans with all Rps genes except for Rps8 and three alleles at a single locus: Rps1a, 1c, and 1k. For two independent loci to be segregating in these populations, one of the loci must be novel or a novel allele of a known locus.

One of the populations, PI398440, segregated for a single gene to both $\mathrm{OH} 17$ and $\mathrm{OH} 25$ in both the $\mathrm{F}_{2: 3}$ and $\mathrm{F}_{2: 4}$ populations. Since $P$. sojae isolates $\mathrm{OH} 17$ and $\mathrm{OH} 25$ together have virulence to all known Rps genes, it is likely that PI398440 contains a novel gene (Table 4). However, since the families did not respond the same to these two isolates, undescribed virulence corresponding to novel Rps genes may be present. If unidentified virulences are present in these isolates to undescribed Rps genes, there are two questions. First and foremost, are these Rps genes worth pursuing for incorporation and deployment in new germ plasm? The answer is probably "no" since populations of $P$. sojae may already exist that are virulent to the new genes. This is not an unusual finding. $P$. sojae isolates that had a susceptible interaction with Harosoy were widespread, as this cultivar was used as the susceptible check long before Rps7 was actually identified. It was not until $P$. sojae isolates were identified that had a resistant reaction on Harosoy that this resistance gene was discovered (9). The second question, then, is "are these Rps genes at novel loci or are they alleles of previously described loci?" A molecular analysis which maps the resistance genes in each of these populations can aid in addressing this question (12).

This subset of South Korean soybean PIs has great potential for novel Rps genes to deploy in order to continue to effectively manage Phytophthora root and stem rot. Vavilov (25) proposed that sources of resistance to highly specialized plant pathogens are often found in regions of the greatest differentiation within the host species. In theory, both host and pathogen have co-evolved in these regions, and this protracted association has led to diversity. The mountainous regions of central and western China, together with the adjacent lowlands, were first proposed as the center of origin for soybeans (25). Secondary and tertiary centers have also been described that include a much larger geographic region encompassing almost all of China and North and South Korea $(18,25)$. The presence of multiple Rps genes, which confer different responses to $P$. sojae as well as the high degree of partial resistance in many of these PIs previously identified (11), suggests that this region is a center for $P$. sojae-soybean interactions.

It will be necessary to continue to identify novel Rps genes as seed companies and universities continue to deploy resistant commercial cultivars and germ plasm, and as $P$. sojae populations continue to adapt to these genes and to increase in diversity and complexity. Deployment of single Rps genes has been a very effective means to manage Phytophthora root and stem rot. Genetic mapping in both the $\mathrm{F}_{2: 3}$ and $\mathrm{F}_{2: 4}$ populations of these PIs is in progress as is the development of additional populations for allelism studies and germ plasm for future use in deployment of soybean cultivars with novel resistance to $P$. sojae.

\section{ACKNOWLEDGMENTS}

We thank R. Fioritto, S. McIntyre, and B. Sugerman for development of plant populations; A. Mills, J. Mills, and K. Burnham for assistance with plant inoculations; and B. Bishop for assistance with data analysis. This project was sponsored by Ohio's soybean producers' check-off dollars through the Ohio Soybean Council. Salaries and research support were provided by state and federal funds appropriated to the Ohio Agricultural Research and Development Center, The Ohio State University, Wooster, $\mathrm{OH}$.

\section{LITERATURE CITED}

1. Abney, T. S., Melgar, J. C., Richards, T. L., Scott, D. H., Grogan, J., and Young, J. 1997. New races of Phytophthora sojae with Rps1-d virulence. Plant Dis. 81:653-655.

2. Athow, K. L. 1985. Phytophthora root rot of soybean. Pages 575-581 in: World Soybean Res. Con. III: Proceedings. R. Shibles, ed. Westview Press, Boulder, CO. 
3. Beuerlein, J. E., St. Martin, S. K., Dorrance, A. E., and Kroon Van Diest, C. D. 2004. Ohio Soybean Performance Trials. Ohio State University Horticulture and Crop Science Series 212

4. Borges, R., Martinka, M. J., Bures, K. A., Gaska, M. M., Grau, C. R., and Kurtzweil, N. K. 2004. 2004 Wisconsin Soybean Variety Test Results. University of Wisconsin-Extension Publication UWEX A3654.

5. Brooks, W. S, Griffey, C. A., Steffenson, B. J., and Vivar, H. E. 2000. Genes governing resistance to Puccinia hordei in thirteen spring barley accessions. Phytopathology 90:1131-1136.

6. Buchwaldt, L., Anderson, K. L., Morrall, R. A. A., Gossen, B. D., and Bernier, C. C. 2004. Identification of lentil germ plasm resistant to Colletotrichum truncatum and characterization of two pathogen races. Phytopathology 94:236-243.

7. Burnham, K. D., Dorrance, A. E., Francis, D. M., Fioritto, R. J., and St. Martin, S. K. 2003. Rps8, A new locus in soybean for resistance to Phytophthora sojae. Crop Sci. 43:101-105.

8. Burnham, K. D., Francis, D. M., Dorrance, A. E., Fioritto, R. J., and St. Martin, S. K. 2002. Genetic diversity patterns among Phytophthora resistant soybean plant introductions based on SSR markers. Crop Sci. 42:338-343.

9. Buzzell, R. I., and Anderson, T. R. 1992. Inheritance and race reaction of a new soybean Rps 1 allele. Plant Dis. 76:600-601.

10. Dorrance, A. E., McClure, S. A., and deSilva, A. 2003. Pathogenic diversity of Phytophthora sojae in Ohio soybean production fields. Plant Dis. 87:139-146.

11. Dorrance, A. E., and Schmitthenner, A. F. 2000. New sources of resistance to Phytophthora sojae in the soybean plant introductions. Plant Dis. 84:1303-1308

12. Gordon, S. G., Kowitwanich, K., Pipatpongpinyo, W., St. Martin, S. K., and Dorrance, A. E. 2007. Molecular marker analysis of soybean plant introductions with resistance to Phytophthora sojae. Phytopathology 97:113-118.

13. Grau, C. R., Dorrance, A. E., Bond, J., and Russin, J. 2004. Fungal diseases. Pages 679-763 in: Soybeans: Improvement, Production and Uses. 3rd ed. H. R. Boerma and J. E. Specht, eds. Agron. Monogr. 16. Am. Soc. Agron., Crop Sci. Soc. Am., and Soil Sci. Soc. Am., Madison, WI.
14. Kaitany, R. C., Hart, L. P., and Safir, G. R. 2001. Virulence composition of Phytophthora sojae in Michigan. Plant Dis. 85:1103-1106.

15. Kurle, J. E., and El Araby, E. M. 2001. Changing composition of Phytophthora sojae races in Minnesota soils. (Abstr.) Phytopathology 91(suppl.):S51.

16. Kyle, D. E., Nickell, C. D., Nelson, R. L., and Pedersen, W. L. 1998. Response of soybean accessions from provinces in southern China to Phytophthora sojae. Plant Dis. 82:555-559.

17. Layton, A. C., Athow, K. L., and Laviolette, F. A. 1984. Inheritance of resistance to Phytophthora megasperma f. sp. glycinea in a soybean plant introduction. Plant Dis. 68:1080-1083.

18. Leppik, E. E. 1970. Gene center of plants as sources of disease resistance. Annu. Rev. Phytopathol. 8:323-344.

19. Lohnes, D. G., Nickell, C. D., and Schmitthenner, A. F. 1996. Origin of soybean alleles for Phytophthora resistance in China. Crop Sci. 31:487488.

20. Malvick, D. K., and Grunden, E. 2004. Traits of soybean-infecting Phytophthora populations from Illinois agricultural fields. Plant Dis. 88:1139-1145.

21. Rennie, B. D., Buzzell, R. I., Anderson, T. R., and Beversdorf, W. D. 1992. Evaluation of four Japanese soybean cultivars for Rps alleles conferring resistance to Phytophthora megasperma f. sp. glycinea. Can. J. Plant Sci. 72:217-220.

22. Schmitthenner, A. F. 1985. Problems and progress in control of Phytophthora root rot of soybean. Plant Dis. 69:362-368.

23. Schmitthenner, A. F., and Bhat, R. G. 1994. Useful methods for studying Phytophthora in the laboratory. OARDC Special Circular 143.

24. Singh, P. K., and Hughes, G. R. 2005. Genetic control of resistance to tan necrosis induced by Pyrenophora tritici-repentis, races 1 and 2, in spring and winter wheat genotypes. Phytopathology 95:172-177.

25. Vavilov, N. I. 1949-1950. The origin, variation, immunity, and breeding of cultivated plants. Chron. Bot. 13:1-364.

26. Yang, X. B., Ruff, R. L., Meng, X. Q., and Workneh, F. 1996. Races of Phytophthora sojae in Iowa soybean fields. Plant Dis. 80:1418-1420.

27. Zar, J. H. 1984. Biostatistical Analysis. Prentice Hall, Englewood Cliffs, NJ. 